\title{
THE REFORM OF THE ITALIAN LOCAL GOVERNMENT ACCOUNTING SYSTEM. A CRITICAL ANALYSIS
}

\author{
Eugenio Caperchione $^{1}$
}

\begin{abstract}
In 1995 the Italian Parliament passed a measure that introduced some significant innovations in the accounting system of Italian local governments.

According to their promoters, these innovations should have improved the overall quality of decisions and increased public efficiency, thanks to the availability of targeted and reliable economic information.

At the same time, Municipalities and Provinces should have implemented - in accordance with the trends currently emerging in the leading Western countries - an accrual-based accounting system, that should have led to assessing with fuller knowledge of the facts whether local governments are managed by considering intergenerational equity.
\end{abstract}

Today, six years after the introduction of the decree many expectations have been disappointed, while there is no proof of significant improvement - i) neither in the quality of economic information, ii) nor in the quality of the decisions taken by local governments.

This paper aims at documenting a series of elements of objective difficulty in the implementation of the 1995 reform, thereby discussing their possible causes and feasible solutions.

To this end, the paper provides some data about the framework of Italian local governments and then briefly examines the reasons behind the 1995 reform.

The paper then moves on to illustrate the contents of the reform, thereby chiefly dwelling upon the introduction of accrual-based financial reporting.

It finally focuses on a sample of 23 local governments that produced these reports for the first time in 1998, and highlights a series of problems that emerged with regard to both communicational efficacy and fair presentation.

The conclusions summarize the major gaps between the reform's objectives and actual effects, and tries to grasp the reasons for these gaps and formulate some suggestions in order to re-design the system.

KEY WORDS: Italy, public sector accounting, reform design \& implementation, accountability, financial reporting.

JEL Codes: H72, M41.

\footnotetext{
${ }^{1}$ EUGENIO CAPERCHIONE, Ph.D., is a lecturer in the University of Modena and Reggio Emilia and a senior lecturer in SDA Bocconi-Bocconi University School of Management, Milan, Italy. Email: eugenio.caperchione@uni-bocconi.it. He has been a visiting professor in the Academy of Economics, Cracow, Poland, and the University of Klagenfurt, Austria. He is a standing member of the Scientific committee of the CIGAR network (Comparative International Governmental Accounting Research).
} 


\section{Local government in Italy}

There are four levels of government in Italy: central government (Parliament and the Cabinet), regional government (20 Regions), provincial government (103 Provinces), and municipal government (8102 Municipalities). Each level is multi-functional in that it has jurisdiction over several issues and activities. Provinces and municipalities are often referred to as "local governments" (LGs).

Each municipality has a mayor, a cabinet, a city council and a professional bureaucracy. The mayor is the head of the executive, is elected directly by the citizens and appoints the members of the cabinet. The city council is also elected directly by the citizens. Municipalities are allowed to (i) raise local taxes and (ii) charge tariffs for the services they provide, but a large percentage of their inflows (27\% on average in 1998) ${ }^{1}$ is still represented by transfers from higher levels of government. Transfers are classified as "current" or "capital" according to whether they are intended to cover operating expenditures or to fund investments.

Provinces have a similar system, although their taxing authority is much more limited, also due to the fact that provinces play a somewhat limited role in the production of services and act mainly as re-distributors of resources.

On the contrary, municipalities have always played a pivotal role in the Italian administration system, both with regard to political representation and because they must produce a number of services which are of the utmost importance to the citizenry, including day nurseries, school lunches and transport, public transport, waste disposal, waterworks, the construction and management of sports centres, the management of public green areas, and the management of nursing homes for the elderly.

These services are provided partly free of charge and partly against payment of a sum which is usually lower (at times much lower) than production cost.

\section{The reasons behind the 1995 reform}

There is no professional public-sector standards-setting body in Italy. The requirements for governmental accounting, reporting and auditing are set by national legislation. Applicable laws are different for central government, regions and LGs. The basic requirements, however, have always been traditionally similar for all levels, and chiefly lie in curbing public spending.

As a consequence, the adopted bases of accounting up until 1995 were obligation and cash. In addition, budgeting was viewed as the only relevant phase of the accounting cycle, while financial reports were virtually neglected. Finally, bookkeeping was based on the single-entry system, which emphasized budgetary compliance.

This system - which is basically very similar to the other cash-based accounting systems historically adopted by public administration in nearly all Western countries - had its own underlying logic and, all things considered, met quite well the needs of the historical period in which it had been conceived and implemented. 
In the course of time, however, some totally new events occurred - and, to a large extent, are still occurring today - that shook the foundations of Italian public administration and, in particular, of Italian local governments:

- a trend to devolve greater organizational, managerial and economic autonomy to individual local governments;

- contracting-out - ever since 1990 LGs have been encouraged to spin off their activities to (i) separate entities without legal autonomy, (ii) separate legal entities with budgetary autonomy, (iii) consortia of LGs, or (iv) joint-stock corporations with private and public stockholders. Alternatively, LGs can also franchise private firms to provide services;

- definition of exact financing mechanisms linked to indispensable activities. Extra resources should be raised by levying taxes and tariffs to be paid by citizens (also following the commitments arising from the 1992 Maastricht Treaty, that entailed a progressive disengagement of European Union central governments in the financing of local governments);

- consequent greater accountability for the pursuit of economic balance and for servicerelated results, i.e. performance.

Thus, some limits of the then used accounting system gradually emerged as both scholars and actors continually maintained, in successive stages, that an accounting reform was badly needed.

In particular, also in accordance with international literature, the following limits were highlighted:

- short-sightedness of the systems. The time horizon of accounting systems, and more specifically of financial reports, only covered the short term, while no reliable information on the impact of policies in the medium to long term was available;

- poor readability of financial statements and consequent difficulty in assessing results. Some governmental accounting systems still date back to periods when the sensitivity to certain values, such as the citizens' right to information, was not strongly felt. Every change in this respect entails a lever to introduce different ways to prepare and present economic information, that best respect the citizens' sovereignty and their "right to know" (GASB, 1987: § 56);

- difficulty in assessing intergenerational equity. The incapacity to determine the value of assets and liabilities and to recognize expenses and revenues on the accrual basis, as well as the often immoderate resort to borrowing as a source of income makes it impossible to assess whether a generation is living "within its means" (Anthony, 1983) or if it is consuming resources it is not producing. This situation is by itself an incentive to "non-economic" behavior, that is "disrespectful for the balance between generations" (Lüder et al., 1991: 68, 262-263);

- poor "usefulness for decision-making purposes" of the information generated by the accounting systems. Financial resources are allocated to the various organizational units or cost centres of each LG through the budget, according to a pre-defined 
framework. Since, due to formal control reasons, this framework cannot be overridden all through the following book-keeping and reporting stages, it takes on a predominant role in the LG administration system. Consequently, the output of the accounting system does not include the production of periodic reports that are organized on the basis of different frameworks, autonomously decided by each LG and linked to actual management processes (for instance, costs by service unit, costs by project).

In 1993 an ad hoc committee was thus set up by the Ministry of the Interior. This committee was comprised of representatives coming from different professional fields (mainly LG Directors of Accounting) and held the task of drawing up a LGA reform, that was chiefly aimed at designing a system that would increase the degree of accountability of each individual LG.

The reform raised the following expectations:

- every key player should have available information consistent with the kind of responsibility they are assigned;

- citizens and other stakeholders should be kept informed on the achievements of local governments, on the reasons behind failures and mistakes, and on the reasons on the basis of which a single LG establishes price levels and taxation pressure;

- the distinction between the roles, tasks and accountability of political representatives and public managers in budgeting, accounting and control;

- the need to understand the cost of programmes and services provided to citizens (public accountability);

- the need for management control systems to help public managers in the decisionmaking process;

- in general terms, management efficiency and effectiveness and the quality of decisions should be improved;

- the cases of financial crises of local governments should be reduced to a bare minimum, as they turn into a burden on the entire national community.

\section{The key contents of the LGA Act}

The 1995 reform (LGA Act), held in legislative decree ${ }^{2} 77 / 1995$, affected all local governments and provided for a phase-in period which ended in the year 2000.

For the purposes of this paper, it is worth examining separately the innovations concerning:

- budgetary accounting;

- financial accounting.

An overview of these innovations will allow us to better understand the aims of the decree and to assess the gap between expectations and achievements. Obviously enough, there are a number of other innovations, but these are not essential for the purposes of this paper. 


\subsection{Budgetary accounting}

The 1995 reform upheld budgetary accounting as the pivot of the entire LG accounting system. The budget thus continues to be the fundamental document in the political life of LGs, as it reports all the choices made with reference to the subsequent financial year. These choices give rise to legal obligations.

The expenditure forecasted in the budget should be covered by revenues of the same amount. Any balance deficits [i.e. expenditure > revenues] should be made good in the subsequent financial year, by generating more revenues or by cutting expenditure.

Thus, the reform is not particularly innovative in this respect. On the contrary, it establishes a continuum with prior legislation. Nonetheless, some new rules are enforced in order to make sure that patterns of behaviour comply with the traditional principles behind the law. In other words, any changes made to prior legislation are merely a means of ensuring that the traditional accounting standards are complied with.

For instance, the Chief financial officer is required to steadily monitor the balance between revenues and expenditure, starting from the budgeting phase in which he/she must formulate an assessment of truthfulness and reliability.

The only significant innovation contained in the decree with regard to budgetary accounting, concerns the separation of the budget into two documents:

- the budget approved by the city (or provincial) council. Its framework has been slightly modified, with a reduction in the number of votes and their aggregation by larger intervention areas, with a view to presenting the councillors with the clearest vision possible of the significance of the choices they make;

- the "management executive plan", a document that is derived from the budget and that authorizes every public manager (staff, officers) to spend the resources available to the LG. This document also includes the management goals to be achieved by each manager, who is annually assessed (and rewarded) on the basis of his/her performance.

This latter document is actually producing positive effects in some LGs, as - on the one hand - the managers have been made fully accountable for the achievement of set goals and, on the other, they now enjoy decisional autonomy they have never had before.

Nonetheless, the reform is not bound to produce positive effects, also because its actual implementation suffers from the discretionary margins that both the mayor and the cabinet still enjoy, and neither of them are always willing or able to establish a relationship of trust and collaboration with managers. This means that, whenever they feel it advisable, they can adopt solutions that strongly limit the managers' margins for manoeuvre. ${ }^{3}$

Moreover, this can entail the risk of incurring the same decision-making problems met in the past by public managers. These problems could stem from:

- too much focus on fiscal compliance and accountability instead of managerial accountability;

- too much emphasis on the budget and little weight given to the performance measurement; 
- more attention to input than output and outcome since goals and objectives are largely buried in detail;

- little flexibility since deviations from detailed appropriation breakdowns require City council approval;

- little attention to the overall effectiveness or efficiency of the organizational unit.

\subsection{Financial accounting}

The LGA Act provided that - besides the reports of budgetary accounting - LGs would annually produce the financial reports typical of an accrual accounting system:

- income statement;

- balance sheet.

The production of these documents should remedy the limits of budgetary accounting discussed above for two reasons.

Firstly, accrual-based statements allow LGs' financial positions to be better evaluated , since they give information about the increase or decrease in equity that an LG has experienced during a fiscal year. Consequently, it is also possible to check whether an LG is maintaining some equilibrium between generations.

Secondly, the availability of reliable cost data can make it easier to analyse the economic impact of decisions. ${ }^{4}$

Law 194/1996 established the format of these documents, to be drawn up in a uniform and compulsory manner by all local governments.

The reports' layouts are similar to those mandated on Italian private companies following the Fourth European Community Directive. ${ }^{5}$ In the income statement, in particular, expenses are classified only by nature (see Table 1). 
TAble 1 - Income Statement for the Year Ended 31 December 20x1

A - Operating Revenue

1 - Taxation revenue

2 - Transfers from other government entities

3 - Revenue from exchange transactions

4 - Investment income

5 - Other operating revenues

6 - Charges for building permissions

7 - Capitalized costs

8 - Increase in inventories

(A) = Total Operating Revenue

B - Operating Expenses

9 - Wages, salaries and employee benefits

10 - Supplies and consumables used

11 - Decrease in inventories

12 - Expenses for services

13 - Expenses for leases

14 - Operating grants and contributions

15 - Tax expense

16 - Depreciation

(B) = Total Operating Expenses

(+A-B) Operating Balance

$C$ - Income and expenses on public-owned enterprises

17 - Dividends

18 - Capital interests

19 - Grants and contributions to public-owned enterprises

$=$ Total $(C)$

Surplus (deficit) from Operating Activities = $(+A-B+C)$

D - Financial Revenues and Costs

20 - Interests earned

21 - Finance costs

(D) = Total financial revenues and charges

E - Proceeds and Charges from Extraordinary Items

22 -Decrease in Liabilities

23 - Increase in Assets

24 - Gains on sale of property, plant and equipment

(E1) $=$ Total Extraordinary Proceeds

25 - Decrease in Assets

26 - Losses on sale of property, plant and equipment

27 - Losses on Receivables

28 - Extraordinary Charges

(E2) $=$ Total Extraordinary Charges

$(E)=(+E 1-E 2)=$ Net Surplus (deficit) from Extraordinary Items

Net Surplus (deficit) for the Period $=(+A-B+C+D+E)$

Source: Law 194/1996 
At first sight, it would seem that the accrual accounting system is "soon done" in Italian public administration.

However, before formulating any final judgements, it is necessary to:

1. see whether or not the provisions of the law are appropriate or if they are somehow wanting and imprecise in some regards;

2. verify on the spot the impact of the reform on a sample of local governments (see next paragraph).

As far as the first issue is concerned, a series of observations should be made.

A first element of concern is the fact that the layouts are manifestly defective, which makes it difficult for accountants to carry out their job.

For instance, the balance sheet layout does not include any provisions for risks and future expenses under liabilities, and it is not clear where exactly the appropriations to these provisions should be entered in the income statement. Consequently, local governments have two main options:

1. not to record these items. This would nevertheless result into a limit to the presentation of a true and fair view, as the economic and financial position of an entity cannot be properly assessed;

2. include these items in external liabilities. This behaviour would also be improper, because they are not payables yet as the entity is merely setting aside some amounts in order to cover future and uncertain risks or specific liabilities for which it is impossible to determine either the exact amount or the actual contingency date at the end of the financial year.

As it can be inferred, neither of these two options make it easy to compare data among entities, nor do they ensure that entities produce quality financial statements.

Another issue to be taken into consideration concerns the accounting treatment of some transactions and the measurement of some goods, that are both typical of local governments and that cannot be treated or measured by the same standards applicable to enterprises, because i) they are transactions typical of public administration, and ii) accounting standards should be adapted or redesigned.

Tax collection, fines and sanctions, fixed assets which cannot be disposed of (streets, bridges, historical buildings, natural resources) obviously represent accounting problems that enterprises have never had to deal with.

TABLE 2 - LIST OF ASSETS WHICH ARE SPECIFIC TO LGS (AS OPPOSED TO PRIVATE COMPANIES)

\begin{tabular}{|l|l|l|}
\hline Artwork & Heritage assets & Rivers and lakes \\
\hline Bridges & Land improvements & Roads \\
\hline Drainage systems & Levees and canals & Sewerage treatment plans \\
\hline Easements & Library books & Traffic control equipment \\
\hline Fire trucks & Police special equipment & Water systems \\
\hline Firefighting equipment & Recreational facilities & \\
\hline
\end{tabular}


At the same time, the appropriation of central government resources tied to the finalization of investments (capital transfers), which also concerns private enterprises, may require local governments to treat these items in a special way (since both the donor and the recipient of government grants belong to the public sector).

In this regard, a set of accounting standards that can guide the action of public accountants is strongly advisable. This has already been done in other countries while, at an international level, a series of standards and exposure drafts has been issued by the IFAC Public Sector Committee. ${ }^{6}$ But in Italy no decision has yet been taken so far in order to either make explicit reference to the accounting standards issued abroad or to start a significant work of autonomous production. If we consider that, under the Italian legal system, neither the standard practice nor suggestions from scholars can compensate for the lack of legal provisions, it is understandable that the issue of reports on the accrual basis of accounting is still a difficult task for accountants. ${ }^{7}$

Moving on to the issue of fixed assets (which will be dealt with in greater depth in the paragraph on implementation), it can be noticed that:

- the LGA Act establishes fixed depreciation rates;

- in order to measure fixed assets, some criteria are envisaged that simplify the preparation of the very first balance sheet; however, no accounting standards are set forth for some items, e.g. shareholdings, and this makes it hard to compare results among entities (Mussari, 2000).

Another issue of the utmost importance concerns the fact that the introduction of doubleentry bookkeeping is not compulsory. Alternatively, LGs can stick to the traditional singleentry obligation- and cash-based accounting system and produce accrual-based financial statements through a system of year-end adjusting entries.

Table 3 provides an example of the adjustment process with specific reference to supplies. A specific "reconciliation statement" must be included in the financial statement to reconcile the cash- and obligation-based statement with the income statement. 


\section{TAble 3 - Producing aCCRUAL-BaSed finANCial STATEMENTS}

FROM CASH AND OBLIGATION-BASED ACCOUNTING: AN EXAMPLE

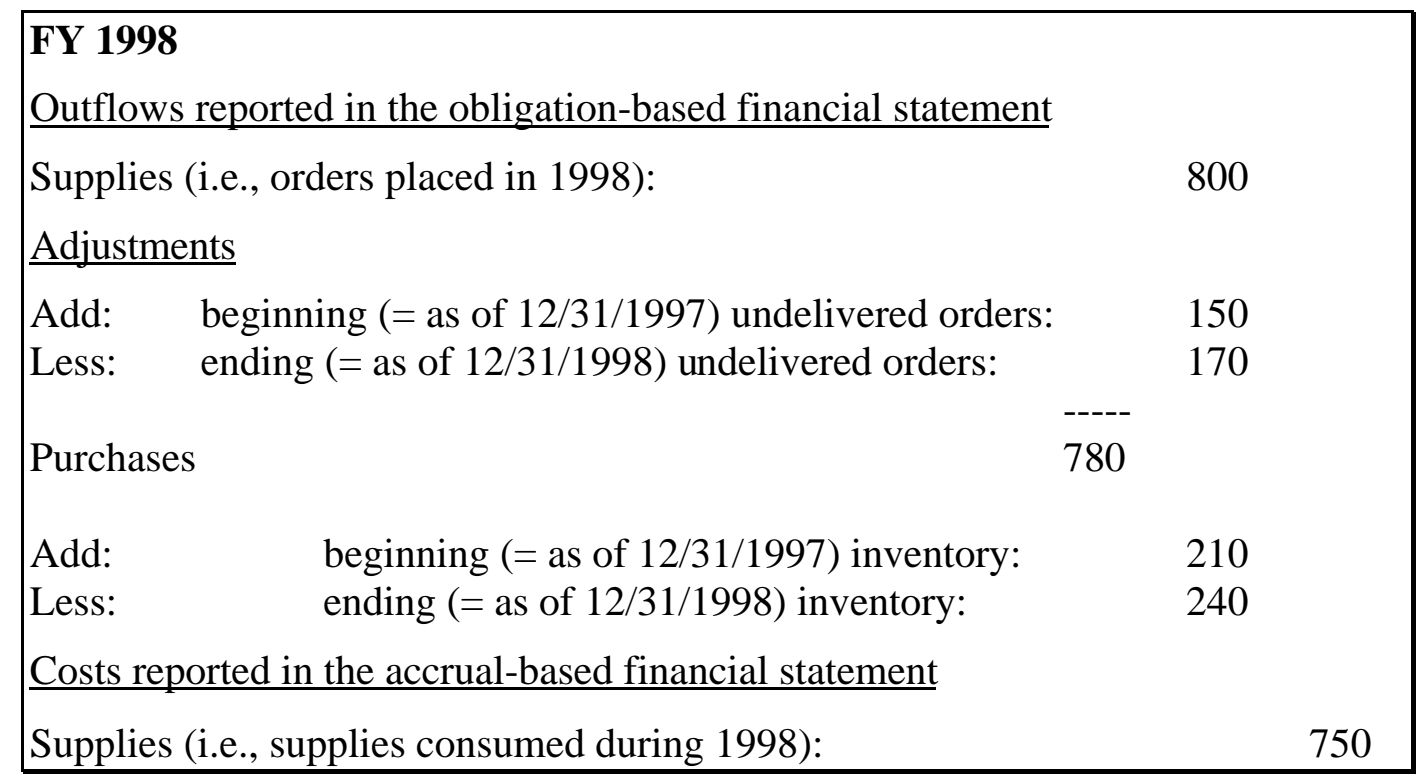

Source: Borgonovi- Anessi Pessina (1998).

Since costs are obtained from expenditure information, this document is deemed sufficient in order to introduce financial reporting based on accrual.

It is true that this simplification can somehow favor start-up, especially in smaller municipalities that are lacking in trained staff and are used to traditional cash accounting. However, critical analysis (Caperchione, 1996) and experience (see following paragraphs) show that this entails a heavy loss of significance in accounting documents.

In particular, the main problems stem from the fact that the values of the budgetary accounting system refer to the obligations made by an entity, that is a stage in the spending procedure that comes before the actual purchase of a good or service.

The following example can cast light on consequences. In November 2001 the Alfa Municipality places an order for a BPR research study worth Euro 100,000 with Beta consulting firm, to be closed by March 2002. At the end of 2001 the firm has produced only the first progress report.

The use of budgetary accounting data leads one to think that the Municipality has incurred costs for Euro 100,000 and, since it has not paid anything yet, external liabilities also amount to Euro 100,000.

On the contrary, the accrual logic leads one to think that the Municipality has no external liabilities, since the consulting job is not over yet, nor has it been invoiced, and therefore the Municipality has incurred no costs at all in 2001.

These events of time variance between obligation and assessment are obviously very frequent in everyday reality. Their number makes it practically impossible to reconstruct 
them ex post, so the system of drawing up accrual-based reports by deriving them from budgetary accounting produces low quality reports.

Nonetheless, most LGs still follow this route, which epitomizes their poor awareness of the importance of reliable accounting information inspired by the accrual logic.

In actual fact, the risk is that accrual-based book-keeping will never find its place on the agenda, as it is not strictly necessary to accomplish the requirements of the law.

This forecast is reinforced by another consideration. The central government is keeping in function some control mechanisms on the financial situation of LGs, both during the budgeting stage and at the year end. However, since this control is still based on cash accounting, the income statement will be likely to be paid very little attention , independently of how it is produced.

Finally, it should be made clear that any decisions on the production of "accrual-inspired" reports without an accrual-based bookkeeping system, necessarily bring about the following problems:

- managers not having any intra-annual statements of costs and expenses;

- great space being left to window-dressing policies;

- great difficulty in drawing up consolidated accounts for LGs with investments in subsidiaries and associates.

\section{The implementation of accrual reporting}

\subsection{The sample examined}

The section of the 1995 LGA Act concerning the introduction of accrual-based financial reporting was enforced only in 1997.

Municipalities with a population of over 100,000 inhabitants (except some larger cities) and their relative provincial governments had to prepare an income statement and a balance sheet for FY 1997 (January $1^{\text {st }}$ - December $31^{\text {st }}$ ). ${ }^{8}$ 
TABLE 4 - DEADLINES FOR THE INTRODUCTION OF ACCRUAL-BASED FINANCIAL REPORTS

\begin{tabular}{|c|c|c|c|c|}
\hline $\begin{array}{l}\text { Size range of } \\
\text { municipality (\# of } \\
\text { inhabitants) }\end{array}$ & $\begin{array}{c}\text { \# of } \\
\text { municipalities }\end{array}$ & $\begin{array}{c}\text { First FY for } \\
\text { accrual-based } \\
\text { reports }\end{array}$ & $\begin{array}{c}\# \text { of } \\
\text { municipalities } \\
\text { to start with } \\
\text { accrual }\end{array}$ & $\begin{array}{c}\text { \# of provinces } \\
\text { to start with } \\
\text { accrual }\end{array}$ \\
\hline$<500$ & 836 & \multirow{6}{*}{2000} & \multirow{6}{*}{5,873} & \\
\hline $500-1,000$ & 1,115 & & & \\
\hline $1,000-2,000$ & 1,702 & & & \\
\hline $2,000-3,000$ & 1,014 & & & \\
\hline $3,000-4,000$ & 699 & & & \\
\hline $4,000-5,000$ & 507 & & & \\
\hline $5,000-10,000$ & 1,169 & \multirow{5}{*}{1999} & \multirow{5}{*}{2,063} & \multirow{5}{*}{12} \\
\hline $10,000-15,000$ & 429 & & & \\
\hline $15,000-20,000$ & 178 & & & \\
\hline $20,000-30,000$ & 183 & & & \\
\hline $30,000-40,000$ & 104 & & & \\
\hline $40,000-50,000$ & 32 & \multirow{3}{*}{1998} & \multirow{3}{*}{$129^{(*)}$} & \multirow{3}{*}{56} \\
\hline $50,000-65,000$ & 50 & & & \\
\hline $65,000-80,000$ & 20 & & & \\
\hline $80,000-100,000$ & 18 & \multirow{4}{*}{1997} & \multirow{4}{*}{$37^{(*)}$} & \multirow{4}{*}{35} \\
\hline $100,000-250,000$ & 34 & & & \\
\hline $250,000-500,000$ & 6 & & & \\
\hline$>500,000$ & 6 & & & \\
\hline Total amount & 8,102 & & 8,102 & 103 \\
\hline
\end{tabular}

(") The subtotals do not coincide because 9 major cities, despite their size, have been authorised to start with FY 1998.

In detail, 72 LGs in all, i.e. 37 municipalities and 35 provinces, had to produce the accrualbased reports for FY 1997 by June 1998.

Given the problems expounded in the foregoing paragraphs of this paper, it might be worth verifying by an empirical analysis how accrual accounting has been implemented in these local governments. In fact, the 1997 financial statements can help to verify on the field whether and how LGs are managing to fulfil the requirements of the law, and what gaps still remain to be bridged.

During the $4^{\text {th }}$ quarter of 1998 a survey was conducted and the 72 local governments were contacted in order to obtain their 1997 financial statements (which, according to the law, include both accrual-based reports and the traditional, obligation- and cash-based reports of budgetary accounting).

All the requested documents were sent by 25 out of 72 LGs, i.e.13 Municipalities and 12 Provinces (see Table 5). 
TABLE 5 - RATE OF RESPONDENTS

\begin{tabular}{|l|c|c|c|}
\hline & $\begin{array}{c}\text { Number of } \\
\text { LGs } \\
\text { contacted }\end{array}$ & $\begin{array}{c}\text { Number of } \\
\text { respondent } \\
\text { LGs }\end{array}$ & $\begin{array}{c}\text { Respondents } \\
\%\end{array}$ \\
\hline $\begin{array}{l}\text { Northern } \\
\text { Italy }\end{array}$ & 35 & 19 & $54 \%$ \\
\hline Central Italy & 14 & 4 & $29 \%$ \\
\hline $\begin{array}{l}\text { Southern } \\
\text { taly }\end{array}$ & 23 & 2 & $9 \%$ \\
\hline Country & 72 & 25 & $35 \%$ \\
\hline
\end{tabular}

As to the 47 LGs that did not collaborate to the survey:

- 5 of them (11\%) stated they had not yet prepared their 1997 financial statements;

- 2 of them (4\%) asked for a payment of over 50 before they would send any documents;

- 40 of them (85\%) simply did not reply.

A telephone survey was then carried out in the early months of 1999 with the aim of assessing - albeit on the basis of the verbal declarations made by the relevant chief financial officers - how many of the 72 LGs contacted had actually fulfilled the obligation to draw up accrual-based reports.

The conclusion is that the obligation had been met by 49 of the 72 LGs (68\%).

The defaulting LGs are mainly found in the South (11 out of 23 defaulting LGs). It should be also be noted that 4 of the 23 defaulting LGs (17\%) already believed they would not be able to comply with the law for FY 1998 either, so they were bound to be running late.

With regard to the alleged reasons for not preparing the reports, many officers stated that LGs are not ready to manage the change due to the obsolescence of hardware technology and the lack of suitable application software.

In order to correctly assess the conclusions we are going to reach in this section of the paper, it is worth noticing that the manner in which the sample was built entails a risk of distortion. The 25 Local Governments that sent their statements could be either those with better performance and better financial results or those more attentive to citizens-oriented communication issues. The sample could thus be distorted upwards.

Given this premise, the work carried out on the 25 LGs included:

a) an examination of the communicational effectiveness of financial statements ( $\$ 4.2$ );

b) an assessment of the truthfulness and reliability of the data gathered and elaborated in the financial statements ( $\S 4.3$ and 4.4$)$.

Given these goals, the following steps were carried out:

- an examination of the formal attitude of financial statements to act as citizens-oriented communication tools (carried out through a series of parameters: graphics, length, relative weight of figures and descriptions, indexes and contents, circulation of the financial statement); 
- a study of the contents of the "statement reports", in order to:

- assess whether LGs had included in this document any extra information useful for interpreting management performance;

- verify, with regard to the items subject to measurement, whether and to what extent LGs i) complied with the directions of the law, if available, and ii) if not, formulated acceptable criteria;

- a study of the reports' structure, aimed at investigating whether LGs integrated or modified the official layouts in order to improve the quality of information;

- an examination of the values entered in financial statements, so to detect aspects of homogeneity and, in some cases, a few drawing-up mistakes.

\subsection{The formal attitude to communicate}

The analysis of the communicational effectiveness was carried out at two levels:

1. the degree of care given by preparers to the exterior and aesthetic aspects of financial statements;

2. the integration of reports with notes (see the following paragraph).

In particular, with regard to the first issue, the following was observed:

- the graphic layout of financial statements (use of images and colors, paper quality, exterior aspect of the cover);

- the material structure of financial statements (length of the document in terms of pages and number of volumes);

- indexes and contents held in financial statements;

- the relative weight of figures and descriptions;

- the ratio between the number of accrual accounting pages and the number of budgetary accounting pages;

- the publication of financial statements on WEB sites;

- whether or not financial statements were free of charge to anyone who requested them.

TABLE 6 - COMMUNICATION POLICY IN GENERAL

\begin{tabular}{|l|cc|cc|}
\hline & yes & $\%$ & no & $\%$ \\
\hline $\begin{array}{l}\text { Significant attention to } \\
\text { graphic aspects }\end{array}$ & 5 & 20 & 20 & 80 \\
\hline Index is present & 13 & 52 & 12 & 48 \\
\hline $\begin{array}{l}\text { Statements published on } \\
\text { the WeB }\end{array}$ & 1 & 4 & 24 & 96 \\
\hline $\begin{array}{l}\text { Delivery of statements free } \\
\text { of charge }\end{array}$ & 18 & 72 & 7 & 28 \\
\hline
\end{tabular}

The main data that emerged from the survey were the following: 
- only 5 out of 25 LGs (20\%) paid due attention to financial statements and their graphic layouts, which denotes their lack of interest in external communications right from the first impact;

- with regard to the length of the accounts, $4 / 25$ (16\%) had less than 100 pages, $18 / 25$ (72\%) had between 100 and 400 pages, and 3/25 (12\%) had 600 or more pages. One of these had nearly 1600 pages of accounts;

- an index was found in 13 out of 25 accounts (52\%), which means that quite a few LGs produced accounts which were awkward to consult, thus prolonging the time needed to obtain necessary information;

- although nearly all LGs have got their own Internet site, just one of them (4\%) published its final accounts on it, which is further proof of the poor attention paid to relationships with considerable users groups;

- 7 out of 25 LGs (28\%) asked for a payment in order to deliver the statements.

TABLE 7 - SIZE OF FINANCIAL REPORTS

\begin{tabular}{|l|c|c|}
\hline Local government unit & Number of volumes & Total \# of pages \\
\hline City council of Novara & 1 & 43 \\
\hline City council of Trieste & 1 & 70 \\
\hline Province of Perugia & 1 & 86 \\
\hline Province of Lecce & 1 & 87 \\
\hline Province of Piacenza & 1 & 106 \\
\hline City council of Ravenna & 1 & 111 \\
\hline Province of Rimini & 3 & 127 \\
\hline City council of Parma & 1 & 153 \\
\hline City council of Latina & 1 & 154 \\
\hline City council of Brescia & 1 & 156 \\
\hline City council of Messina & 1 & 169 \\
\hline City council of Bergamo & 1 & 171 \\
\hline Province of Ferrara & 1 & 173 \\
\hline Province of Vicenza & 1 & 203 \\
\hline City council of Modena & 2 & 210 \\
\hline Province of Bergamo & 2 & 232 \\
\hline Province of Verona & 3 & 233 \\
\hline City council of Leghorn & 1 & 251 \\
\hline Province of Parma & 1 & 269 \\
\hline Province of Prato & 3 & 304 \\
\hline City council of Forli & 2 & 359 \\
\hline City council of Piacenza & $\mathbf{1 . 7}$ & 386 \\
\hline City council of Reggio Emilia & 2 & 595 \\
\hline Province of Modena & 217 \\
\hline Province of Trento & 1 & \\
\hline Mean of the 25 LGs & 1 & 621 \\
\hline
\end{tabular}

Moving on to the importance actually attributed to descriptions (in the sense that a page does not contain any accounting tables, but only explanations), the analysis is limited to the 23 LGs - out of the 25 that replied to our request for information - that actually drew up accrual-based reports. 
From this analysis, it can be noted that only 10 out of these 23 LGs (43\%) drew up descriptive pages on accrual accounting; 6 of them produced less than 5 descriptive pages and another 6 dedicated these pages almost exclusively to the cabinet's report on the implementation of programmes.

Finally, accrual-based reports clearly have less room than obligation- and cash-based reports: 12 out of 23 LGs (52\%) dedicated less than $10 \%$ of the pages in their statements to accrual accounting.

TABLE 8 - COMMUNICATION POLICY IN ACCRUAL-BASED REPORTS

\begin{tabular}{|l|cc|cc|}
\hline & yes & $\%$ & no & $\%$ \\
\hline Descriptive pages on accrual & 10 & 43 & 13 & 57 \\
\hline 5 or more pages on accrual & 4 & 19 & 17 & 81 \\
\hline $\begin{array}{l}\text { Technical comments or } \\
\text { thorough explanations } \\
\text { provided }\end{array}$ & 4 & 19 & 17 & 81 \\
\hline $\begin{array}{l}\text { Accrual-related pages } \\
\text { exceeding 10\% of total pages }\end{array}$ & 11 & 48 & 12 & 52 \\
\hline
\end{tabular}

\subsection{Notes to the Financial Statements}

The Local Government Accounting Act requires the Notes to the financial statements to be produced, but does not exactly define their contents.

Nevertheless, a general consensus exists both in doctrine and among experts on the relevance of information disclosure; thus, scholars suggest to enrich the Notes by taking business accounting as a model.

For this reason, the notes submitted by the 23 LGs that actually produced accrual-based reports were carefully scrutinized, seeking in them (even if some adjustments were necessary) the same information demanded by law from business enterprises. 
TABLE 9 - ACCOUNTING POLICIES

\begin{tabular}{|l|cc|c|}
\hline Line-items & $\begin{array}{c}\text { \# of LGs zeroing } \\
\text { the entry }\end{array}$ & $\begin{array}{c}\text { \# of LGs with item } \\
\text { value > 0 }\end{array}$ & $\begin{array}{c}\text { \# of LGs } \\
\text { explaining } \\
\text { accounting policy }\end{array}$ \\
\hline Capitalized costs & 18 & 5 & 2 \\
\hline $\begin{array}{l}\text { Public domain } \\
\text { assets }\end{array}$ & 1 & 22 & 4 \\
\hline Land & 1 & 22 & 3 \\
\hline Buildings & - & 23 & 5 \\
\hline $\begin{array}{l}\text { Plants, equipment, } \\
\text { furniture }\end{array}$ & - & 23 & 1 \\
\hline $\begin{array}{l}\text { Real right on third } \\
\text { party goods }\end{array}$ & 21 & 2 & 5 \\
\hline Financial assets & 1 & 22 & 3 \\
\hline Depreciation & 6 & 17 & 3 \\
\hline Inventories & 8 & 15 & - \\
\hline Short-term bonds & 3 & 20 & \\
\hline $\begin{array}{l}\text { Provisions for risks } \\
\text { and future expenses }\end{array}$ & Item not mentioned in LGA Act & \\
\hline
\end{tabular}

A series of interesting questions arise in regard to measurement criteria, which can also be seen in table 9:

- only a small number of LGs explained the criteria used for the measurement of their various assets ( 5 or less, depending on the asset considered);

- those that actually explained the criteria, generally limited themselves to a formal repetition of the guidelines defined by law, without offering any added information; which, however, would have been in most cases necessary, due to the lack of specifications in the law;

- there are some items that a large amount of LGs did not give a value to. In particular, 8 LGs out of $23(35 \%)$ attributed a value equal to zero to inventories on December $31^{\text {st }}$, 1997; 18 LGs out of 23 (78\%) did not present any capitalized costs values; and 21 out of $23(91 \%)$ did not attribute any value at all to real rights on third party goods. This kind of behavior generates some perplexities, especially if it is considered that in the case of real rights on third party goods it is pretty unlikely that only two LGs had these kinds of assets. It is much more likely that the LGs had zeroed the entry to avoid complicated measurement procedures and thus simplified the preparation of their financial statement;

- finally, provisions for risks were not entered by any of the 23 LGs. As it has already been stated, the law did not mention the recording of this item in the liabilities of the balance sheet; consequently, none of the LGs recorded this item to the detriment of the significance of financial statements;

- not all the LGs that entered an item in the assets, bothered to consequently depreciate it: for example, out of 5 LGs that included deferred capitalized costs with a given value other than zero in the assets, only 1 gave a depreciation rate. This could perhaps be explained by the reluctance of LGs to enter costs (even if this means "bending" accounting rules). 
With regard to any extra information that can be presented in a statement report, it can be seen that:

- only 5 LGs out of $23(22 \%)$ disclosed interesting explanations on the movements of balance sheet items;

- 7 LGs out of 17 that held shareholdings in their portfolios (41\%) dedicated a section in the report to the composition of the portfolio; none of them, however, disclosed all the information requested by law from businesses;

- no LG classified assets and liabilities by maturity;

- 5 LGs out of 18 (28\%) explained the composition of accrued income and prepaid expenses;

- 5 LGs out of 16 (31\%) explained accrued liabilities and deferred income.

\subsection{The financial reports, their structure and the quality of data}

In order to measure the degree of reliability of the data gathered, an analysis was carried out on the layout of the financial statements, on the way they were compiled, on the entries devised and modified and on any possible abnormalities.

The following main issues emerged:

- in regard to the layout used for reporting, all LGs used the official layouts contained in the LGA Act. 3 LGs out of 23 (13\%) enriched their reports with extra tables, that flanked the official ones without substituting them;

- in regard to the layout of the income statement, 3 LGs out of the 23 examined (13\%) made slight modifications to the layout of the document: one Municipality appropriately added an extra item that the law had not envisaged (yearly quotas of deferred revenues), while the other two specified the contents of some items and shifted items within the income statement. In all cases, these changes resulted in users' needs being satisfied in a more correct manner;

- in regard to the layout of the balance sheet, 11 LGs out of 23 (48\%) added or modified items. In particular, 4 gave details on capital transfers on the basis of their final destination (the financing of public works or the re-transfer of sums to third parties). In this case too, the efforts that have been made to adapt layouts to the specific realities of some LGs should be appreciated.

The limited degree of reliability of the data disclosed in the reports makes it extremely risky to carry out any cross-analysis on the 1997 financial statements of the Local Governments examined.

Nevertheless, some issues are worth noting (see Table 10):

- 4 Municipalities out of 12 (33\%) (and no provinces) presented a negative operating balance; 
- after entering the values relative to "Income and expenses on public-owned enterprises", only 1 Municipality out of $12(8 \%)$ presented a deficit from operating activities; the 11 Provinces continued to attain a surplus;

- finance costs exceeded interest earned in 21 of the 23 LGs examined (91\%);

- 6 LGs out of $23(26 \%)$ presented extraordinary charges higher than extraordinary proceeds;

- 4 LGs out of 23 (17\%) presented a deficit for the period;

- on the other hand, the year-end budgetary balance was positive for all the LGs in the panel.

TABLE 10 - Positive AND NEGATIVE VALUES IN INCOME STATEMENTS

\begin{tabular}{|c|c|c|c|c|c|c|}
\hline & \multicolumn{2}{|c|}{ Municipalities } & \multicolumn{2}{|c|}{ Provinces } & \multicolumn{2}{|c|}{ Total } \\
\hline & + & - & + & - & + & - \\
\hline Operating balance $=\mathrm{A}-\mathrm{B}$ & 8 & 4 & 11 & 0 & 19 & 4 \\
\hline $\begin{array}{l}\text { Surplus (deficit) from } \\
\text { Operating Activities }=(+A- \\
\text { B+C) }\end{array}$ & 11 & 1 & 11 & 0 & 22 & 1 \\
\hline $\begin{array}{l}\text { (D) = Total financial } \\
\text { revenues and charges }\end{array}$ & 1 & 11 & 1 & 10 & 2 & 21 \\
\hline $\begin{array}{l}\text { E) }=(+\mathrm{E} 1-\mathrm{E} 2)=\mathrm{Net} \\
\text { Surplus (deficit) from } \\
\text { Extraordinary Items }\end{array}$ & 10 & 2 & 7 & 4 & 17 & 6 \\
\hline $\begin{array}{l}\text { Net Surplus (deficit)for the } \\
\text { Period }=(+A-B+C+D+E)\end{array}$ & 11 & 1 & 8 & 3 & 19 & 4 \\
\hline Year-end budgetary balance & 12 & 0 & 11 & 0 & 23 & 0 \\
\hline
\end{tabular}

The difference between accrual and cash based reports is highly relevant. Accrual-based reports start to unveil a series of problems that traditional budgetary accounting does not even take into consideration (see Table 11).

Furthermore, through the study of the tables, some other aspects were observed like calculation mistakes (that generate incoherence among values) and a number of abnormalities (total assets differing from total liabilities, net surplus differing from the change in net equity) which denote the unreliability of some financial statements, probably due to the fact that they were drawn up without double-entry bookkeeping. 


\section{TABLE 11 - THE MAIN SOURCES OF VARIATION BETWEEN BUDGETARY AND ACCRUAL ACCOUNTING}

\begin{tabular}{|l|l|l|}
\hline Accrued income & Accrued liabilities & Capital grants \\
\hline Capitalized costs & Decrease in Assets & Decrease in Liabilities \\
\hline Deferred income & Depreciation & $\begin{array}{l}\text { Gains on sale of property, } \\
\text { plant and equipment }\end{array}$ \\
\hline Increase in Assets & Increase in inventories & Losses on Receivables \\
\hline $\begin{array}{l}\text { Losses on sale of property, } \\
\text { plant and equipment }\end{array}$ & Prepaid expenses & Provisions \\
\hline $\begin{array}{l}\text { Value added tax (taxation } \\
\text { prepayment) }\end{array}$ & & \\
\hline
\end{tabular}

In conclusion, it is worth reflecting briefly on some critical items, that are difficult to assess objectively:

1. intangible assets;

2. inventories;

3. accrued income;

4. prepaid expenses;

5. net equity from public domain assets;

6. accrued liabilities;

7. deferred income.

These are totally new items for Italian LGs: thus, in many cases the values attributed to them was zero.

Therefore, we ranked the LGs on the basis of the number of critical items assigned zerovalue, in order to verify any correlation between this behavior (zeroing the value of critical items) and other patterns of behavior that emerged earlier in the analysis (see Table 12).

TABLE 12: LGS AND CRITICAL ITEMS

\begin{tabular}{|c|c|c|l|}
\hline $\begin{array}{c}\text { Number of zero- } \\
\text { value items }\end{array}$ & \# of LGs & $\%$ & List of LGs \\
\hline 7 & 1 & $4 \%$ & Province of Prato \\
\hline 6 & 2 & $9 \%$ & Provinces of Verona and Lecce \\
\hline 5 & 2 & $9 \%$ & Municipalities of Leghorn and Latina \\
\hline 4 & 7 & $30 \%$ & $\begin{array}{l}\text { Municipalities of Trieste, Bergamo, Brescia, } \\
\text { Porli } \\
\text { Provinces of Vicenza, Piacenza, Parma }\end{array}$ \\
\hline 3 & 4 & $17 \%$ & $\begin{array}{l}\text { Municipalities of Novara, Piacenza } \\
\text { Provinces of Bergamo, Perugia }\end{array}$ \\
\hline 2 & 5 & $22 \%$ & $\begin{array}{l}\text { Municipalities of Parma, Modena, Ravenna } \\
\text { Provinces of Ferrara, Rimini }\end{array}$ \\
\hline 1 & 2 & $9 \%$ & $\begin{array}{l}\text { Municipality of Reggio Emilia } \\
\text { Province of Modena }\end{array}$ \\
\hline & 23 & $100 \%$ & \\
\hline
\end{tabular}


This list is rich with information, especially if it is correlated to the relevance given to the accrual accounting pages and the descriptive pages contained in financial statements (see Table 8):

- the Municipality of Reggio Emilia and the Province of Modena, that annulled the least number of critical items, were also the ones that produced the highest number of accrual accounting-descriptive pages. This means that their management dedicated great care and attention to helping the public understand the functioning of accrualbased accounting;

- the Provinces of Prato and Lecce did not write any accrual accounting-descriptive pages, while the Province of Verona only wrote one. This could be the reason why so many critical items were assigned zero values.

By referring to the list, it is possible to chart Italy on the basis of the modalities adopted by LGs for the realization of the accrual-based accounting prospectuses. On the basis of available data it can be stated that:

- the LGs that zeroed the highest number of critical items were in southern and central Italy;

- the LGs that zeroed the lowest number of critical items were in northern Italy and especially in the Emilia-Romagna Region.

The performance of this latter Region is very interesting. As a matter of fact, in EmiliaRomagna there was the highest concentration of LGs that submitted their reports by the first deadline (16 out of the 72 Local Governments in the whole country that should have submitted their 1997 statements, i.e. 22\%). This surely favored opportunities for a number of meetings among chief financial officers throughout the Region, with a view to correctly implementing the reform. The situation was quite different though in Central and Southern Italy, where LGs found themselves alone in facing the many problems linked to the functioning of the new accounting system.

\section{The gap between the reform's objectives and its actual effects}

The examination carried out on the sample of 23 LGs that produced accrual-based reports for FY 1997, together with other considerations on the real behavior of LGs, leads to affirm that the real effects of the LGA Act only partly coincide with the expectations. 


\section{TABLE 13 - EXPECTATIONS AND ACTUAL EFFECTS OF THE ITALIAN LGA REFORM}

\begin{tabular}{|c|c|c|}
\hline Reform's objectives & reform's instruments & reform's real effects \\
\hline $\begin{array}{l}\text { - to control public spending (fiscal } \\
\text { compliance and accountability) } \\
\text { to understand the cost of } \\
\text { programmes and services provided } \\
\text { to citizens (public accountability) }\end{array}$ & $\begin{array}{l}\text { - new object classification } \\
\text { structure }\end{array}$ & $\begin{array}{l}\text { - standard level of details (such as } \\
\text { uniform organisational units) which do } \\
\text { not exactly match the actual } \\
\text { organisational units and the distribution } \\
\text { of responsibilities } \\
\text { the budget document does not enable } \\
\text { full understanding of the public services } \\
\text { it represents. The City Council } \\
\text { members feel obliged to check details } \\
\text { of expenditures } \\
\text { diverting attention from the important } \\
\text { policy decisions that set the levels of } \\
\text { public services. }\end{array}$ \\
\hline $\begin{array}{l}\text { - the distinction between the roles, } \\
\text { tasks and accountability of political } \\
\text { representatives and public managers } \\
\text { in budgeting, accounting and control }\end{array}$ & $\begin{array}{ll}\text { - } & \text { management executive plan } \\
\text { administrative and financial } \\
\text { control }\end{array}$ & $\begin{array}{l}\text { - } \text { highly detailed expenditure line- } \\
\text { itemisation } \\
\text { - City Councils are claiming a right to } \\
\text { information in order to analyse and to } \\
\text { influence the management executive } \\
\text { plan during budget adoption } \\
\text { - more attention to input than output } \\
\text { - little flexibility } \\
\text { - little attention to the overall } \\
\text { effectiveness or efficiency }\end{array}$ \\
\hline $\begin{array}{l}\text { - to improve efficiency and } \\
\text { effectiveness using public resources }\end{array}$ & 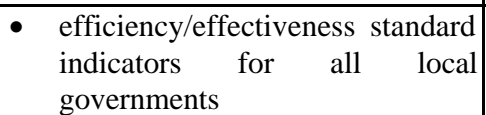 & $\begin{array}{l}\text { - lesser attention on statements of goals } \\
\text { and objectives }\end{array}$ \\
\hline $\begin{array}{l}\text { - the need for management control } \\
\text { systems to help public managers in } \\
\text { decision-making }\end{array}$ & $\begin{array}{l}\text { - } \text { efficiency/effectiveness standard } \\
\text { indicators for all local } \\
\text { governments } \\
\text { benchmarking with other local } \\
\text { governments } \\
\text { planned expenditure in the } \\
\text { management executive plan }\end{array}$ & $\begin{array}{l}\text { - lesser attention on real effective } \\
\text { managerial control systems } \\
\text { - not homogeneous cost of services for } \\
\text { comparability } \\
\text { - public managers need to plan expenses } \\
\text { for the year, not only expenditures }\end{array}$ \\
\hline $\begin{array}{l}\text { - } \begin{array}{l}\text { analysis of fiscal position and } \\
\text { performance }\end{array} \\
\text { pron }\end{array}$ & $\begin{array}{l}\text { - accrual accounting } \\
\text { - a reconciliation statement (costs } \\
\text { are obtained from expenditure) } \\
\text { - a statement of revenues and } \\
\text { expenses } \\
\text { - a statement of assets and liability } \\
\text { - a statement of entries and } \\
\text { expenditures } \\
\text { more aggregated line-item } \\
\text { budget structure for little local } \\
\text { governments with regards to } \\
\text { entries and expenditures }\end{array}$ & $\begin{array}{l}\text { - little municipalities, with the use of this } \\
\text { new statement, will avoid the } \\
\text { introduction of double-entry book- } \\
\text { keeping } \\
\text { - budget document refer only to } \\
\text { explaining of expenditures and receipts } \\
\text { on a liability and receivable basis } \\
\text { not homogeneous financial reports } \\
\text { about entries and expenditures }\end{array}$ \\
\hline $\begin{array}{l}\text { - to avoid fiscal crisis of local } \\
\text { governments during the fiscal year }\end{array}$ & 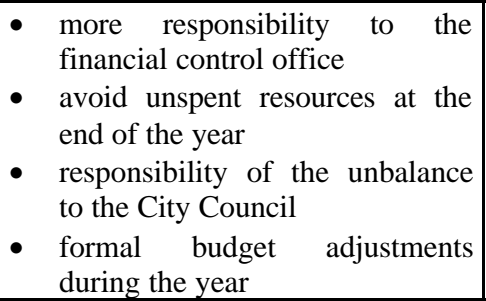 & 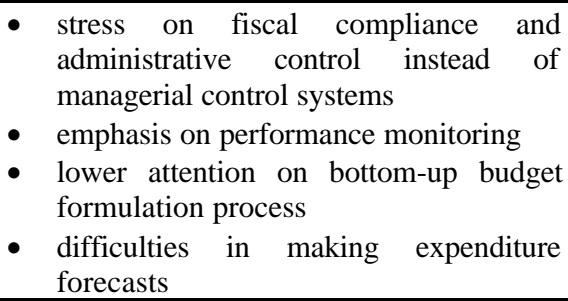 \\
\hline
\end{tabular}


As shown in Table 13, the discrepancy between intentions and realization is in many cases remarkable.

In particular, it should be highlighted that:

- obligation- and cash-based accounting continues to prevail over accrual accounting, in regard to all issues related to the functioning of LGs, starting from the definition of current transfers and capital transfers. It is certain that for a number of years pressure will still be put upon cash data, more than on accrual data. This obviously will not generate more attention being given to the quality of accrual accounting;

- given the different accounting treatments, it is still quite difficult to compare the results attained by different Local Governments, and to put some pressure on those which underperform;

- the new system still does not permit to identify reliable efficiency and effectiveness indicators, that can truly help managers take decisions;

- only a few LGs are building cost accounting systems;

- accrual reports are, at least for now, virtually unusable and do not create any opinion flows or political debates. The time devoted to their discussion during the budget session is irrelevant.

Thus, all things considered, it can hardly be said that the reform has considerably improved the levels of accountability in LGs.

\section{Guidelines for a new and more effective reform}

The lack of achievement presented in the previous sections can be traced to a variety of factors.

Moreover, since Italy is a civil law country, it goes without saying that the solution to the various problems relating to Local Government Accounting will necessarily require a change in the law.

A new LGA reform, conceived with the objective of supplying Public Administration modernization with a really effective tool, should probably tackle the following issues:

1. the specific information needs of the different kinds of institutions must be identified;

2. the accounting system has to be consistent with the core elements of the Public Administration system;

3. accounting cannot be used for a large number of objectives.

With reference to the first issue, different information needs can be found in connection with:

- the goals of the institution examined;

- its size and degree of complexity;

- the types of decisions that the organization must normally take; 
- the different information users;

- the services offered, the financing mechanisms and in general all the factors which can make the management of an organization different from that of others.

The second group of key factors sees accounting as one of the varied tools that can be used in managing public organizations, so the need to make accounting consistent with every other innovation becomes clearer.

The main factors that reform-makers should consider are the following:

- the overall structure of the public sector, and how functions and tasks are attributed to different organizations and levels of government;

- the public financing mechanisms, especially concerning the distinction between a centralized and a decentralized fiscal system;

- the degree of pricing autonomy granted to LGs;

- citizens' needs and demands;

- the actual operational systems used by different organizations (management control, personnel management, information system, etc.);

- the prevailing organizational culture.

It is not necessary to explain the relations between accounting and every single variable reported in this list. Nevertheless, it is perhaps important to highlight a principle: the greater the autonomy given or achieved by a local government, the greater the need for accounting systems which report true information on its financial position (namely, accrual accounting). This becomes extremely important if we consider that any unbalance between revenues and costs ultimately reduces the citizens' wealth and leads to increased taxation or to a reduction of the services offered.

Finally, with regard to the third issue, it must be noticed that in Italy many functions, which are often inconsistent with one another, all fall into one single accounting system:

a) authorization function;

b) management control function;

c) financial flow regulation;

d) monetary policy.

The first function is typical of the public sector in general. In different ways, it can be found in the legislation of nearly every country.

The second function is linked to the need to obtain useful information from the accounting system in order to make programmes and to control processes.

Finally, in regard to the last two functions, it must be observed that, following the Maastricht Treaty commitments, the Central Government is more and more frequently limiting LGs' autonomy, imposing by law that current year expenditure should not exceed prior year expenditure. 
All these functions, as already stated, are managed through the official accounting system, which however cannot answer so many different kinds of needs properly; thus, the adoption of specific mechanisms for each one of them could certainly improve the quality and reliability of information. ${ }^{9}$

Once the need for a new reform has become clear, and some general questions have been answered, we can take another step forward in order to discuss:

1) the process to adopt in order to design and implement the reform;

2) the reform's contents;

3) any relations between Italian laws and those of other European countries.

As far as the first point is concerned, it must be said that, for a number of reasons, any reform would quite probably be introduced top-down. A procedure of this kind, as it can be observed by looking to the reform processes of several countries, has a greater chance of success if the following conditions are available:

- the system is accurately planned starting from a conceptual framework and ending in a complex and orderly design of LGs;

- an intensive experimental period follows;

- the scopes of the reform are clearly explained together with the significance that should be given to performance, thus creating awareness and consensus;

- accounting professionals enjoy autonomy to introduce the necessary adaptations or modifications;

- an adequate degree of accounting culture exists within LGs, or the right conditions are created so that managers and staff update their knowledge;

- cultural and financial resources are available for a careful revision of management procedures, that must become consistent with the accounting system, so to allow an effective and timely gathering of basic data;

- accounting standards especially designed for LGs are made available in a relatively short period;

- more generally, those that impose the reform also show an interest in the attainment of good results, and provide benchmarking occasions, as well as the necessary financial, human, HW \& SW resources.

It is difficult to state that these conditions have been regularly guaranteed to Italian LGs over the last six years. Therefore, we cannot be surprised neither by the fact that the results achieved are not in line with expectations, nor by the fact that LGs do not invest resources and energy on accrual accounting.

With regard to the second point, the time has probably come to switch over from traditional budgetary accounting to accrual accounting. This change would affect all of the system components:

- budgeting (output and outcome budgeting could replace cash appropriations); 
- accounting (to be done with double-entry book-keeping);

- financial reporting (income statement and balance sheet should be the core statements);

- performance evaluation (since LGs are accountable for the quantity and quality of services provided).

With relation to the third issue, it should be considered that the introduction of the Euro in 12 EU countries reinforces the need for convergence of LGA systems - some kind of regional harmonization could in effect allow comparisons to be made more easily, and this could certainly result into a pressure towards higher accountability.

\section{Conclusions}

In 1995 the Italian Government passed a law reforming Local Government Accounting.

At that time there was general consent on the limitations of previous regulations; nevertheless, this did not lead to a well-conceived reform.

The trend towards accrual accounting that has been sweeping through Western countries for the last few years (Caperchione, 2000), has had a partial impact only on Italian LGs. Accrual reporting has been introduced, but double-entry book-keeping has not. Budgetary accounting still remains crucial, and is used to prepare both budgetary and accrual reports. Consequently, the innovation heralded by the law is more formal than substantial, and LGs are not driven to increase their accountability.

A survey conducted on a sample of LGs confirms the weaknesses of this reform.

As far as external communication is concerned, financial reports prepared after the reform do not help citizens in understanding the financial situation of Local Governments: figures are not explained, final results are not discussed, some mistakes or bugs shorten their overall reliability.

Local Governments have been left alone in the implementation of the reform. This has driven a group of administrations (mainly located in the Emilia-Romagna Region, having the highest concentration of LGs switching over to the new system from the very beginning) to start collaborating with one other to find a solution to the many open questions. $^{10}$

An overall judgement on the 1995 reform must emphasize the following issues:

- obligation- and cash-based accounting continues to prevail over accrual accounting;

- very little attention is being paid to the quality of accrual accounting;

- cost accounting systems are hardly a priority for LGs;

- accrual reports are not an instrument for anybody in the political bargain.

Suggested stages for a more substantial improvement can then be represented by:

- the adoption of a full accrual system, to be used for both budgeting and reporting;

- the consequent dismissal of the traditional cash accounting system; 
- a more comprehensive use of performance measures.

Clearly, these kinds of innovations would require a high degree of consent, in order to be correctly implemented. Thus, such a reform can only be introduced if LGs are allowed to contribute to designing the reform, and are helped throughout the implementation phase.

Finally, a new accounting system can really work only if accountability and responsibility mechanisms are introduced: should this not be the case, no accounting system will ever have major effects on the performance of Local Governments.

\section{Acknowledgements}

Address for correspondence: Eugenio Caperchione, Facoltà di Economia, viale Berengario 51, 41100 Modena MO, Italy. E-mail <caperchione@unimo.it>

The author would like to thank anonymous reviewers and the editor of this journal for their helpful comments.

\section{Notes}

${ }^{1}$ Source: personal elaboration of ANCI data (ANCI, National Association of Italian Municipalities).

${ }^{2}$ Under Italian Law, Parliament may decide to delegate legislative powers to the Executive on specific matters. The laws enacted by the Executive under these circumstances are called "Legislative Decrees".

${ }^{3}$ In order to understand the relationships between politicians and managers, it is worth remembering that there are no spoil-system mechanisms in Italy. Managers can be dismissed only for very serious reasons, after a long and complex procedure which is de facto hardly ever adopted.

${ }^{4}$ The move towards resource-accounting is presently a common issue in most OECD countries. For an analysis of the benefits which can be expected by the new system, see - among others - Likiermann (1995) and Brede-Buschor (1993).

${ }^{5}$ As a condition for simpler market relations between member countries, the European Community regulated the annual financial reporting of corporations through the $4^{\text {th }}$ and the $7^{\text {th }}$ Directives, issued respectively in 1978 and 1983. The relatively uniform layouts adopted since then in EU member countries have greatly enhanced the comparability of performance data.

${ }^{6}$ As at June $30^{\text {th }}$, 2001, IFAC has issued 12 International Public Sector Accounting Standards, mainly based on International Accounting Standards.

${ }^{7}$ As an example for this, it can be noticed that no rule has been established for the measurement and the disclosure of inventories.

${ }^{8}$ The deadlines provided for the introduction of accrual-based reports (LGA Act, article 71) are shown in Table 4. It is noteworthy that the municipalities of Turin, Milan, Venice, Genoa, Bologna, Florence, Rome, Bari and Naples had to apply the rules as from FY 1998, i.e. one year later than what would have been normally expected: this was decided in consideration of the higher complexity of the transition. Provincial governments, on the other side, had to apply the regulations in the same year as their capital municipality. 
${ }^{9}$ GASB (1999: § 186) clearly explains that "users need different kinds of financial information for different purposes ", so that any choice on a specific focus of financial statements "may obscure some of the information needed" for specific decisions.

10 Subsequent pieces of research, conducted on FY 1998 (Anessi Pessina-Steccolini, 2000) confirm the difficulties in implementing the 1995 reform.

\section{References}

ANESSI PESSINA Eugenio, STECCOLINI Ileana (2000), “Accruals accounting in Italian Local Governments: Is it working? Can it work?", paper presented at the EIASM Conference, Zaragoza.

ANTHONY, R.N. (1983), Tell it like it was: a conceptual framework for financial accounting, Irwin: Richard D.

BAC Aad (ed.) (2001), International Comparative Issues in Governmental Accounting. The Similarities and Differences between Central Government Accounting and Local Government Accounting within or between Countries, Dordrecht: Kluwer Academic Publishers.

BORGONOVI Elio (1994), "Accounting, legitimation and consensus", paper presented at the $17^{\text {th }}$ European Accounting Association Congress, Venice.

BORGONOVI Elio and ANESSI PESSINA Eugenio (1998), "User needs and financial reporting requirements for Italian Local Authorities", paper presented at Naples International Accounting Conference

BREDE H., BuschOR E. (eds.) (1993), Das neue öffentliche Rechungswesen, "Schriften zur öffentlichen Verwaltung und öffentlichen Wirtschaft", Band 133, Baden-Baden: Nomos.

BUSCHOR Ernst and SCHEDLER Kuno (eds.) (1994), Perspectives on performance measurement and Public sector accounting, Berna: Paul Haupt.

CAPERCHIONE Eugenio (1996), "La tenuta della contabilità per la costruzione del conto economico", in CAPERCHIONE Eugenio (ed.), Il regolamento di contabilità nell'ente locale, Maggioli: Rimini.

CAPERCHIONE Eugenio (2000a), Sistemi informativo-contabili nella pubblica amministrazione. Profili comparati, evoluzione e criteri per la progettazione, Milano: EGEA.

CAPERCHIONE Eugenio (2000b), "Trends and Open Issues in Governmental Accounting Systems: some Elements of Comparison", in CAPERCHIONE Eugenio and MUSSARI Riccardo (eds.), Comparative issues in Local Government Accounting, Boston: Kluwer Academic Publishers.

CAPERCHIONE Eugenio and PEZZANi Fabrizio (eds.) (2000), Responsabilità e trasparenza nella gestione dell'ente locale, Milano: EGEA.

CARPENTER F.H. and SHARP C.F. (1993), Popular reporting: local government financial reports to the citizenry, Norwalk. 
CHAN J.L., JONES R.H., LÜDER K. (eds.) (1996), "Research in Governmental and Nonprofit Accounting", vol. 9, Greenwich: JAI Press.

CHAN James L. (1996), “Characterizing a Nation's Governmental Accounting System”, in LÜDER Klaus (editor), Recent developments in CIGAR, Speyer: Forschungsinstitut.

ChristiaENS Johan (2000), "Municipal accounting reform in Flanders: an empirical study of the outcomes", in CAPERCHIONE Eugenio and MUSSARI Riccardo (eds.), Comparative issues in Local Government Accounting, Boston: Kluwer Academic Publishers.

GASB (1987), Objectives of Financial Reporting, Concepts statement $n$. 1.

GASB (1990), Measurement Focus and Basis of Accounting -Governmental Fund Operating Statements.

GASB (1994), Service Efforts and Accomplishments Reporting, Concepts Statement n. 2.

GASB (1999), Basic Financial Statements - and Management's Discussion and Analysis for State and Local Governments, Statement No. 34.

IASC (2000), International Accounting Standards 2000, London.

IfaC - Public Sector Committee (2000), Governmental Financial Reporting. Accounting Issues and Practices, New York.

ISTAT (1999-a), Compendio statistico nazionale, Roma.

ISTAT (1999-b), Finanza locale: Entrate e spese dei bilanci consuntivi (comuni, provincie e regioni), anno 1996, Roma.

JONES Rowan H. (1992), "The development of conceptual frameworks of accounting for the Public sector", Financial Accountability and Management, vol. 8, n. 4, Oxford: Blackwell.

LIKIERMANN Andrew (1995), Resource Accounting and Budgeting: Rationale and Background, "Public Administration", vol. 73., n. 4.

LÜDER Klaus (1994), “The contingency model reconsidered: experiences from Italy, Japan and Spain", in BUSCHOR Ernst e SCHEDLER Kuno (eds.), Perspectives on performance measurement and Public sector accounting, Bern: Paul Haupt.

LÜDER Klaus and KAMPMANN Brigitte (1993), Harmonisierung des öffentlichen Rechnungswesens in der Europäischen Gemeinschaft, Speyerer Forschungsberichte, nr. 125, Speyer: Forschungsinstitut.

LÜDER, K., Hinzmann, C., KAmPMAnn, B. and OtTE, R. (1991), Vergleichende Analyse öffentlicher Rechnungssysteme. Konzeptionelle Grundlagen für das staatliche Rechnungswesen mit besonderer Berücksichtigung der Bundesrepublik Deutschland, Speyerer Forschungsberichte, n. 97, Speyer: Forschungsinstitut.

MUSSARI Riccardo (2000), "Some considerations on the significance of the assets and liabilities statement in Italian Local Government Accounting Reform", in CAPERCHIONE 
Eugenio and MUSSARI Riccardo (eds.), Comparative issues in Local Government Accounting, Boston: Kluwer Academic Publishers.

Olson O., Guthrie J., HuMPhrey C. (eds.) (1998), Global warning! Debating International Developments in New Public Financial Management, Oslo: Cappelen Akademisk Forlag. 